Damen, N.L., Versteeg, H., Helmondt, S.J. van, Jaegere, P.P. de, Geuns, R.J.M. van, Meine, M.M/m Domburg, R.T. van, Pedersen, S.S. The distressed (Type D) personality mediates the relationship between remembered parenting and psychological distress in cardiac patients- 7 Psychology \& Health: 2014, 29(3), 318-333

\begin{tabular}{|l|l|}
\hline $\begin{array}{l}\text { Postprint } \\
\text { Version }\end{array}$ & 1.0 \\
\hline Journal website & http://www.tandfonline.com/doi/full/10.1080/08870446.2013.845889 \\
\hline Pubmed link & $\underline{\text { http://www.ncbi.nlm.nih.gov/pubmed/24131060 }}$ \\
\hline DOI & $10.1080 / 08870446.2013 .845889$ \\
\hline
\end{tabular}

This is a NIVEL certified Post Print, more info at http://www.nivel.eu

\title{
The distressed (Type D) personality mediates the relationship between remembered parenting and psychological distress in cardiac patients
}

\author{
NikKi L. DAmen ${ }^{\mathrm{A}}$, HenneKe Versteeg ${ }^{\mathrm{AC}}$, SANne J. VAn HelmondT ${ }^{\mathrm{A}}$, Peter P. DE \\ JAEGERE $^{\mathrm{B}}$, ROBERT-JAN M. VAN GEUNS ${ }^{\mathrm{B}}$, MATHIAS M. MEINE ${ }^{\mathrm{C}}$, RON T. VAN DOMBURG ${ }^{\mathrm{B}} \&$ \\ SUSANNE S. PEDERSEN ${ }^{\mathrm{ABDE}}{ }^{*}$
}

\begin{abstract}
Objective: Both the distressed (Type D) personality (i.e. the combination of negative affectivity and social inhibition traits) and dysfunctional parenting styles are associated with anxiety and depression. As parenting styles have been related to personality development, dysfunctional parenting styles may also be associated with Type D personality. We examined whether remembered parenting was associated with anxiety and depression in cardiac patients and whether Type D personality mediated this relationship.

Methods: Our sample comprised 435 patients treated with percutaneous coronary intervention (PCI) and 123 patients with congestive heart failure (CHF). Patients completed the Hospital Anxiety and Depression Scale, Type D Scale (DS14), and Remembered Relationship with Parents (RRP10) scale.

Results: Remembered parenting was significantly associated with higher anxiety and depression levels and Type D personality. In multivariable linear regression analyses, Type D personality accounted for $25-29 \%$ of the variance in anxiety and $23-46 \%$ of the variance in depression, while remembered parenting was no longer significantly associated with these domains. Sobel tests and bootstrapping indicated that Type D personality mediated the relationship between remembered parenting and anxiety and depression.

Conclusion: Type D personality mediated the relationship between remembered parenting and anxiety and depression in both PCI and CHF patients.
\end{abstract}


Damen, N.L., Versteeg, H., Helmondt, S.J. van, Jaegere, P.P. de, Geuns, R.J.M. van, Meine, M.M/m Domburg, R.T. van, Pedersen, S.S. The distressed (Type D) personality mediates the relationship between remembered parenting and psychological distress in cardiac patients Psychology \& Health: 2014, 29(3), 318-333

\section{INTRODUCTION}

The distressed (Type D) personality (i.e. the combination of negative affectivity (NA) and social inhibition (SI) traits) is a risk factor for anxiety and depression (Pedersen et al., 200642. Pedersen, S. S., Ong, A. T. L., Sonnenschein, K., Serruys, $P$. W., Erdman, R. A. M., \& van Domburg, R. T. (2006). Type D personality and diabetes predict the onset of depressive symptoms in patients after percutaneous coronary intervention. American Heart Journal, 151, 367.e361-367.e366. doi: 10.1016/j.ahj.2005.08.012; Pedersen, van Domburg, Theuns, Jordaens, \& Erdman, 200443.Pedersen, S. S., van Domburg, R. T., Theuns, D. A. M. J., Jordaens, L., \& Erdman, R. A. M. (2004). Type D personality is associated with increased anxiety and depressive symptoms in patients with an implantable cardioverter defibrillator and their partners. Psychosomatic Medicine, 66, 714-719.

doi:10.1097/01.psy.0000132874.52202.21; Spindler, Pedersen, Serruys, Erdman, \& van Domburg, 200755. Spindler, H., Pedersen, S. S., Serruys, P. W., Erdman, R. A. M., \& van Domburg, R. T. (2007). Type-D personality predicts chronic anxiety following percutaneous coronary intervention in the drug-eluting stent era. Journal of Affective Disorders, 99, 173-179. doi:10.1016/j.jad.2006.09.009; van Gestel et al., 200759. van Gestel, Y. R. B. M., Pedersen, S. S., van de Sande, M., de Jaegere, P. P. T., Serruys, P. W., \& Erdman, R. A. M. (2007). Type-D personality and depressive symptoms predict anxiety 12 months post-percutaneous coronary intervention. Journal of Infectious Diseases, 103, 197-203.), poor health status and quality of life (Mols, Martens, \& Denollet, 201033. Mols, F., Martens, E. J., \& Denollet, J. (2010). Type D personality and depressive symptoms are independent predictors of impaired health status following acute myocardial infarction. Heart, 96, 30-35. doi:10.1136/hrt.2009.170357; Pedersen, Denollet, Ong, Serruys, et al., 200740. Pedersen, S. S., Denollet, J., Ong, A. T. L., Serruys, P. W., Erdman, R. A. M., \& van Domburg, R. T. (2007). Impaired health status in Type D patients following PCI in the drug-eluting stent era. International Journal of Cardiology, 114, 358-365. doi:10.1016/j.ijcard.2005.12.018; Schiffer et al., 200553. Schiffer, A. A., Pedersen, S. S., Widdershoven, J. W., Hendriks, E. H., Winter, J. B., \& Denollet, J. (2005). The distressed (type D) personality is independently associated with impaired health status and increased depressive symptoms in chronic heart failure. European Journal of Cardiovascular Prevention \& Rehabilitation, 12, 341-346. doi:10.1097/01.hjr.0000173107.76109.6c), and morbidity and mortality in patients with cardiovascular disease (Denollet, Pedersen, Vrints, \& Conraads, 200610. Denollet, J., Pedersen, S. S., Vrints, C. J., \& Conraads, V. M. (2006). Usefulness of Type $D$ personality in predicting five-year cardiac events above and beyond concurrent symptoms of stress in patients with coronary heart disease. The American Journal of Cardiology, 97, 970-973. doi:10.1016/j.amjcard.2005.10.035; Martens, Mols, Burg, \& Denollet, 201030. Martens, E. J., Mols, F., Burg, M. M., \& Denollet, $J$. (2010). Type D personality predicts clinical events after myocardial infarction, above and beyond disease severity and depression. Journal of Clinical Psychiatry, 71, 778-783.; Pedersen et al., 200739. Pedersen, S. S., Denollet, J., Ong, A. T., Sonnenschein, K., Erdman, R. A., \& Serruys, P. W. (2007). Adverse clinical events in patients treated with sirolimus-eluting stents: The impact of Type D personality. European Journal of Cardiovascular Prevention and Rehabilitation, 14, 135-140. doi:10.1097/HJR.0b013e328045c282 00149831-200702000-00020 [pii]; Pedersen, 
Damen, N.L., Versteeg, H., Helmondt, S.J. van, Jaegere, P.P. de, Geuns, R.J.M. van, Meine, M.M/m Domburg, R.T. van, Pedersen, S.S. The distressed (Type D) personality mediates the relationship between remembered parenting and psychological distress in cardiac patients Psychology \& Health: 2014, 29(3), 318-333

Lemos, et al., 200441. Pedersen, S. S., Lemos, P. A., van Vooren, P. R., Liu, T. K. K., Daemen, J., \& Erdman, R. A. M. (2004). Type D personality predicts death or myocardial infarction after bare metal stent or sirolimus-eluting stent implantation: A rapamycin-eluting stent evaluated at rotterdam cardiology hospital (RESEARCH) registry substudy. Journal of the American College of Cardiology, 44, 997-1001. doi:10.1016/j.jacc.2004.05.064), as also confirmed in recent meta-analyses (Denollet, Schiffer, \& Spek, 201011. Denollet, J., Schiffer, A. A., \& Spek, V. (2010). A general propensity to psychological distress affects cardiovascular outcomes. Circulation: Cardiovascular Quality and Outcomes, 3, 546-557. doi:10.1161/circoutcomes.109.934406; Versteeg, Spek, Pedersen, \& Denollet, 201160. Versteeg, H., Spek, V., Pedersen, S. S., \& Denollet, J. (2011). Type D personality and health status in cardiovascular disease populations: A meta-analysis of prospective studies. European Journal of Cardiovascular Prevention \& Rehabilitation, 19, 1373-1380. doi:10.1177/1741826711425338). Type D individuals experience a broad range of negative emotions and tend to inhibit these emotions in social interaction (Denollet, 20057. Denollet, J. (2005). DS14: Standard assessment of negative affectivity, social inhibition, and Type D personality. Psychosomatic Medicine, 67, 89-97. doi:10.1097/01.psy.0000149256.81953.49; Pedersen \& Denollet, 200638. Pedersen, S. S., \& Denollet, J. (2006). Is Type D personality here to stay? Emerging evidence across cardiovascular-disease patient groups. Current Cardiology Reviews, 2, 205-213.).

Several links have been identified that may explain the association between Type D personality and adverse health outcomes in cardiac patients and include both behavioural and biological pathways. Type $\mathrm{D}$ patients are less likely to engage in optimal health-related behaviours, such as exercising and quitting smoking (Pedersen \& Denollet, 200638. Pedersen, S. S., \& Denollet, J. (2006). Is Type D personality here to stay? Emerging evidence across cardiovascular-disease patient groups. Current Cardiology Reviews, 2, 205-213.; Steptoe \& Molloy, 200757. Steptoe, A., \& Molloy, G. J. (2007). Personality and heart disease. Heart, 93, 783-784. doi:10.1136/hrt.2006.109355; Williams, O'Connor, Grubb, \& O'Carroll, 201163. Williams, L., O'Connor, R. C., Grubb, N., \& O'Carroll, R. (2011). Type D personality predicts poor medication adherence in myocardial infarction patients. Psychology \& Health, 26, 703-712. doi:10.1080/08870446.2010.488265) and are also less likely to consult their health care provider despite worrying more about their symptoms (Schiffer, Denollet, Widdershoven, Hendriks, \& Smith, 200752. Schiffer, A. A., Denollet, J., Widdershoven, J. W., Hendriks, E. H., \& Smith, O. R. F. (2007). Failure to consult for symptoms of heart failure in patients with a type-D personality. Heart, 93, 814-818. doi:10.1136/hrt.2006.102822). Biological pathways include immune activation (Conraads et al., 20066. Conraads, V. M., Denollet, J., De Clerck, L. S., Stevens, W. J., Bridts, C., \& Vrints, C. J. (2006). Type D personality is associated with increased levels of tumour necrosis factor (TNF)- $\alpha$ and TNF- $\alpha$ receptors in chronic heart failure. International Journal of Cardiology, 113, 34-38. doi:10.1016/j.ijcard.2005.10.013; Denollet et al., 20038. Denollet, J., Conraads, V. M., Brutsaert, D. L., De Clerck, L. S., Stevens, W. J., \& Vrints, C. J. (2003). Cytokines and immune activation in systolic heart failure: The role of Type $D$ personality. Brain, Behavior, and Immunity, 17, 304-309. doi:10.1016/s08891591(03)00060-6), dysfunctional stress reactivity (Habra, Linden, Anderson, \& Weinberg, 200321. Habra, M. E., Linden, W., Anderson, J. C., \& Weinberg, J. 
Damen, N.L., Versteeg, H., Helmondt, S.J. van, Jaegere, P.P. de, Geuns, R.J.M. van, Meine, M.M/m Domburg, R.T. van, Pedersen, S.S. The distressed (Type D) personality mediates the relationship between remembered parenting and psychological distress in cardiac patien Psychology \& Health: 2014, 29(3), 318-333

(2003). Type D personality is related to cardiovascular and neuroendocrine reactivity to acute stress. Journal of Psychosomatic Research, 55, 235-245. doi:10.1016/s0022-3999(02)00553-6; Williams, O’Carroll, \& O'Connor, 200962. Williams, L., O'Carroll, R. E., \& O'Connor, R. C. (2009). Type D personality and cardiac output in response to stress. Psychology \& Health, 24, 489-500. doi:10.1080/08870440701885616), and disturbances in cortisol regulation (Molloy, Perkins-Porras, Strike, \& Steptoe, 200832. Molloy, G. J., Perkins-Porras, L., Strike, P. C., \& Steptoe, A. (2008). Type-D Personality and cortisol in survivors of acute coronary syndrome. Psychosomatic Medicine, 70, 863-868.

doi:10.1097/PSY.0b013e3181842e0c; Whitehead, Perkins-Porras, Strike, Magid, \& Steptoe, 200761. Whitehead, D. L., Perkins-Porras, L., Strike, P. C., Magid, K., \& Steptoe, A. (2007). Cortisol awakening response is elevated in acute coronary syndrome patients with type-D personality. Journal of Psychosomatic Research, 62, 419-425. http://dx.doi.org.proxy.library.uu.nl/10.1016/j.jpsychores.2006.11.005). However, knowledge of the mechanisms involved in the development of Type D personality itself is largely lacking. A recent study suggested that the characteristics of Type D personality may in part be attributed to genetic factors, as the heritability for Type D was found to be 52\% (Kupper, Boomsma, de Geus, Denollet, \& Willemsen, 201127. Kupper, N., Boomsma, D. I., de Geus, E. J. C., Denollet, J., \& Willemsen, G. (2011). Nine-year stability of Type D personality: Contributions of genes and environment. Psychosomatic Medicine, 73, 75-82.

doi:10.1097/PSY.0b013e3181fdce54). Regarding environmental factors, remembered parenting may be of importance, as dysfunctional parenting styles, like overprotection or coldness, have been related to neuroticism (Furukawa, 199219. Furukawa, T. (1992). Perceived parental rearing, personality and mental status in Japanese adolescents. Journal of Adolescence, 15, 317-322. doi:10.1016/01401971(92)90033-2; McCrae \& Costa, 198831. McCrae, R. R., \& Costa, P. T. (1988). Recalled parent-child relations and adult personality. Journal of Personality, 56, 417-434. doi:10.1111/j.1467-6494.1988.tb00894.x; Reti et al., 200249. Reti, I. M., Samuels, J. F., Eaton, W. W., Bienvenu, O. J., Costa, P. T., \& Nestadt, G. (2002). Influences of parenting on normal personality traits. Psychiatry Research, 111, 5564. doi:10.1016/s0165-1781(02)00128-2), NA (Aron, Aron, \& Davies, 20051. Aron, E. N., Aron, A., \& Davies, K. M. (2005). Adult shyness: The interaction of temperamental sensitivity and an adverse childhood environment. Personality and Social Psychology Bulletin, 31, 181-197. doi:10.1177/0146167204271419) and adult shyness (Aron et al., 20051. Aron, E. N., Aron, A., \& Davies, K. M. (2005). Adult shyness: The interaction of temperamental sensitivity and an adverse childhood environment. Personality and Social Psychology Bulletin, 31, 181-197.

doi:10.1177/0146167204271419). These personality traits are closely related to the two core components of the Type D construct.

In addition, previous studies have indicated that dysfunctional parenting styles are associated with an increased risk of anxiety and depression (Denollet, Smolderen, van den Broek, \& Pedersen, 200712. Denollet, J., Smolderen, K. G. E., van den Broek, K. C., \& Pedersen, S. S. (2007). The 10-item remembered relationship with parents (RRP10) scale: Two-factor model and association with adult depressive symptoms. Journal of Affective Disorders, 100, 179-189.

doi:10.1016/j.jad.2006.10.009; Kendler, Myers, \& Prescott, 200026. Kendler, K. S., Myers, J., \& Prescott, C. A. (2000). Parenting and adult mood, anxiety and 
Damen, N.L., Versteeg, H., Helmondt, S.J. van, Jaegere, P.P. de, Geuns, R.J.M. van, Meine, M.M/m Domburg, R.T. van, Pedersen, S.S. The distressed (Type D) personality mediates the relationship between remembered parenting and psychological distress in cardiac patien Psychology \& Health: 2014, 29(3), 318-333

substance use disorders in female twins: An epidemiological, multi-informant, retrospective study. Psychological Medicine, 30, 281-294.; Lee \& Hankin, 200928. Lee, A., \& Hankin, B. L. (2009). Insecure attachment, dysfunctional attitudes, and low self-esteem predicting prospective symptoms of depression and anxiety during adolescence. Journal of Clinical Child \& Adolescent Psychology, 38, 219-231. doi:10.1080/15374410802698396; Neale et al., 199434. Neale, M. C., Walters, E., Heath, A. C., Kessler, R. C., Pérusse, D., \& Eaves, L. J. (1994). Depression and parental bonding: Cause, consequence, or genetic covariance? Genetic Epidemiology, 11, 503-522. doi:10.1002/gepi.1370110607; Rapee, 199748. Rapee, R. M. (1997). Potential role of childrearing practices in the development of anxiety and depression. Clinical Psychology Review, 17, 47-67. doi:10.1016/s02727358(96)00040-2). Furthermore, dysfunctional parenting styles have been related to cardiovascular outcomes. Results from the Adverse Childhood Experiences (ACE) study showed that adverse childhood experiences, including household dysfunction, neglect and abuse, are related to an increased risk of ischaemic heart disease (Dong et al., 200413. Dong, M., Giles, W. H., Felitti, V. J., Dube, S. R., Williams, J. E., \& Chapman, D. P. (2004). Insights into causal pathways for ischemic heart disease: Adverse childhood experiences study. Circulation, 110, 1761-1766. doi:10.1161/01.cir.0000143074.54995.7f; Felitti et al., 199816. Felitti, V. J., Anda, R. F., Nordenberg, D., Williamson, D. F., Spitz, A. M., \& Edwards, V. (1998). Relationship of childhood abuse and household dysfunction to many of the leading causes of death in adults: The adverse childhood experiences (ACE) Study. American Journal of Preventive Medicine, 14, 245-258. doi:10.1016/s0749-3797(98)00017-8). Another study with a 35-year follow-up showed that dysfunctional parenting styles were associated with an increased risk of incident coronary artery disease (CAD) (Russek \& Schwartz, 199751. Russek, L. G., \& Schwartz, G. E. (1997). Perceptions of parental caring predict health status in midlife: A 35-year follow-up of the Harvard mastery of stress study. Psychosomatic Medicine, 59, 144-149.).

Because both Type D personality and dysfunctional parenting styles are related to psychological distress and dysfunctional parenting styles may also be associated with Type D personality, Type D may mediate the relationship between remembered dysfunctional parenting and anxiety and depression. Personality factors, such as selfesteem, emotional stability and self-discipline, have been investigated as a mediating mechanism in the relationship between dysfunctional parenting styles and depression (Avagianou \& Zafiropoulou, 20082. Avagianou, P., \& Zafiropoulou, M. (2008). Parental bonding and depression: Personality as a mediating factor. International Journal of Adolescent Medicine and Health, 20, 261-269.; Enns, Cox, \& Larsen, 200015. Enns, M. W., Cox, B. J., \& Larsen, D. K. (2000). Perceptions of parental bonding and symptom severity in adults with depression: Mediation by personality dimensions. Canadian Journal of Psychiatry. Revue Canadienne de Psychiatrie, 45, 263-268.; Parker, 199336. Parker, G. (1993). Parental rearing style: Examining for links with personality vulnerability factors for depression. Social Psychiatry and Psychiatric Epidemiology, 28, 97-100. doi:10.1007/bf00801738). In a recent population-based study, Type D mediated the relationship between remembered parenting and perceived health (van den Broek, Smolderen, Pedersen, \& Denollet, 201058. van den Broek, K. C., Smolderen, K. G., Pedersen, S. S., \& Denollet, J. (2010). Type D personality mediates the relationship between remembered parenting and perceived health. Psychosomatics, 51, 216-224. doi:10.1176/appi.psy.51.3.216), 
Damen, N.L., Versteeg, H., Helmondt, S.J. van, Jaegere, P.P. de, Geuns, R.J.M. van, Meine, M.M/m Domburg, R.T. van, Pedersen, S.S. The distressed (Type D) personality mediates the relationship between remembered parenting and psychological distress in cardiac patients. Psychology \& Health: 2014, 29(3), 318-333

whereas another study demonstrated the mediating role of Type D in the relationship between attachment style and self-esteem (Huis in 't Veld, Vingerhoets, \& Denollet, 201125. Huis in 't Veld, E. M. J., Vingerhoets, A. J. J. M., \& Denollet, J. (2011). Attachment style and self-esteem: The mediating role of Type D personality. Personality and Individual Differences, 50, 1099-1103.

doi:10.1016/j.paid.2011.01.034).

Although both dysfunctional parenting styles and Type D personality have been related to adverse cardiovascular outcomes, to date no study examined this mediation model in cardiac patients. Hence, the aim of the current study was to examine whether remembered parenting is associated with anxiety and depression in cardiac patients, and whether Type D personality mediates this relationship. To examine whether the effects differ between stages of heart disease, we used two cohorts of cardiac patients, patients treated with percutaneous coronary intervention (PCI) and congestive heart failure $(\mathrm{CHF})$ patients.

\section{METHODS}

\section{Participants and procedure}

The study sample included 558 cardiac patients. The first cohort comprised 435 consecutive patients treated with PCI to reflect early-stage heart disease. Patients were treated with PCI between February 2, 2006 and September 14, 2006 at the Erasmus MC, Rotterdam, the Netherlands. In all patients, the paclitaxel-eluting stent was used as the default strategy. No exclusion criteria were applied, and all PCI patients were eligible for enrolment regardless of their anatomical, clinical or psychological presentation. One-month post-PCI, patients were asked to complete a set of standardised and validated psychological questionnaires, as preliminary evidence suggests that psychological assessment at the time of the index PCI may be less optimal than one month post-procedure (Poston, Haddock, Conard, Jones, \& Spertus, 200345. Poston, W. S. C., Haddock, C. K., Conard, M. W., Jones, P., \& Spertus, J. (2003). Assessing depression in the cardiac patient. Behavior Modification, 27, 26-36. doi:10.1177/0145445502238691).

To represent end-stage heart disease, the second cohort comprised 123 patients receiving a first-time cardiac resynchronisation therapy defibrillator (CRT-D) between January 21, 2009 and August 9, 2010 at the University Medical Center Utrecht, the Netherlands. All patients participated in the ongoing 'The influence of PSYchological factors on health outcomes in HEART failure patients treated with CRT: A prospective, single-centre, observational study (PSYHEART-CRT)'. The PSYHEART-CRT study was primarily designed to examine whether psychological factors moderate the effect of objectively assessed CRT response on patient reported outcomes in CHF patients. Exclusion criteria were age $<18$ or $>85$ years, a history of psychiatric illness other than affective/anxiety disorders, cognitive impairments (e.g. dementia), on the waiting list for heart transplantation, and insufficient knowledge of the Dutch language. We did not exclude patients with a history of affective/anxiety disorders, as we are particularly interested in patients with increased levels of depression and anxiety, irrespective of the fact if this has been diagnosed as a disorder. One day prior to implantation, patients were asked to complete a set of standardised and validated psychological questionnaires. 
Damen, N.L., Versteeg, H., Helmondt, S.J. van, Jaegere, P.P. de, Geuns, R.J.M. van, Meine, M.M/m Domburg, R.T. van, Pedersen, S.S. The distressed (Type D) personality mediates the relationship between remembered parenting and psychological distress in cardiac patients Psychology \& Health: 2014, 29(3), 318-333

The current study was approved by the medical ethics committee of the respective hospitals and was conducted in accordance with the Helsinki Declaration (Goodyear, Krleza-Jeric, \& Lemmens, 200720. Goodyear, M. D. E., Krleza-Jeric, K., \& Lemmens, T. (2007). The Declaration of Helsinki. BMJ, 335, 624-625. doi:10.1136/bmj.39339.610000.BE). All patients provided informed consent.

\section{MEAsures}

\section{Socio-demographic and clinical characteristics of PCI patients}

Socio-demographic characteristics included gender and age. Clinical characteristics included multi-vessel disease (multi-vessel disease vs. single-vessel disease/no vessel disease), body mass index (BMI), cardiac history (i.e. previous myocardial infarction (MI), coronary artery bypass graft (CABG) surgery, or PCI), indication for PCI (stable angina, unstable angina, or $\mathrm{MI}$ ), CAD risk factors (i.e. hypertension, diabetes mellitus, family history of CAD, and self-reported smoking) and prescribed cardiac discharge medications (i.e. aspirin, ACE-inhibitors, beta-blockers, calciumantagonists, diuretics, oral nitrates, and statins). Information on socio-demographic and clinical characteristics was obtained from patients' medical records.

\section{Socio-demographic and clinical characteristics of CHF patients}

Socio-demographic characteristics included gender and age. Clinical characteristics included aetiology (ischaemic vs. non-ischaemic), implantable cardioverter defibrillator indication (primary vs. secondary prevention), New York Heart Association (NYHA) functional class, left ventricular ejection fraction (LVEF), BMI, cardiac history (i.e. previous MI, CABG, or PCI), smoking, and prescribed cardiac medication at hospital admission for CRT-D implantation. Information on socio-demographic and clinical characteristics was obtained from patients' medical records.

\section{Type D personality}

In both cohorts, Type D personality was assessed with the 14-item Type D scale (DS14) that comprises two subscales, NA (e.g. I often feel unhappy) and SI (e.g. I am a closed kind of person), each consisting of 7 items. Items are scored on a fivepoint Likert scale, ranging from 0 (false) to 4 (true). Based on findings from Item Response Theory (Emons, Meijer, \& Denollet, 200714. Emons, W. H. M., Meijer, R. $R$., \& Denollet, J. (2007). Negative affectivity and social inhibition in cardiovascular disease: Evaluating Type-D personality and its assessment using item response theory. Journal of Psychosomatic Research, 63, 27-39.

doi:10.1016/j.jpsychores.2007.03.010), a standardised cut-off score $\geq 10$ on both subscales is used to identify individuals with a Type D personality. However, previous studies indicated that Type $\mathrm{D}$ personality is better represented as a continuous construct (Ferguson et al., 200917. Ferguson, E., Williams, L., O'Connor, R. C., Howard, S., Hughes, B. M., \& Johnston, D. W. (2009). A taxometric analysis of Type-D personality. Psychosomatic Medicine, 71, 981-986. doi:10.1097/PSY.0b013e3181bd888b) and could be derived from the interaction effect of the NA and SI subscales (Denollet, Pedersen, Ong et al., 200639. Pedersen, S. S., Denollet, J., Ong, A. T., Sonnenschein, K., Erdman, R. A., \& Serruys, P. W. 
Damen, N.L., Versteeg, H., Helmondt, S.J. van, Jaegere, P.P. de, Geuns, R.J.M. van, Meine, M.M/m Domburg, R.T. van, Pedersen, S.S. The distressed (Type D) personality mediates the relationship between remembered parenting and psychological distress in cardiac patients Psychology \& Health: 2014, 29(3), 318-333

(2007). Adverse clinical events in patients treated with sirolimus-eluting stents: The impact of Type D personality. European Journal of Cardiovascular Prevention and Rehabilitation, 14, 135-140. doi:10.1097/HJR.0b013e328045c282 00149831200702000-00020 [pii]; Whitehead et al., 200761. Whitehead, D. L., Perkins-Porras, L., Strike, P. C., Magid, K., \& Steptoe, A. (2007). Cortisol awakening response is elevated in acute coronary syndrome patients with type-D personality. Journal of Psychosomatic Research, 62, 419-425.

http://dx.doi.org.proxy.library.uu.nl/10.1016/j.jpsychores.2006.11.005). In the current study, we used this interaction term as a continuous measure of Type D personality in all analyses. In the cohort of PCI patients, Cronbach's alphas were .86 for NA and .85 for SI, whereas in the cohort of CHF patients, Cronbach's alphas were .90 for NA and .87 for SI.

\section{Anxiety and depression}

All patients completed the Dutch version of the Hospital Anxiety and Depression Scale (HADS) to assess symptoms of anxiety and depression (Spinhoven et al., 199756. Spinhoven, P., Ormel, J., Sloekers, P. P., Kempen, G. I., Speckens, A. E., \& Van Hemert, A. M. (1997). A validation study of the Hospital Anxiety and Depression Scale (HADS) in different groups of Dutch subjects. Psychological Medicine, 27, 363-370.; Zigmond \& Snaith, 198364. Zigmond, A. S., \& Snaith, R. P. (1983). The hospital anxiety and depression scale. Acta Psychiatrica Scandinavica, 67, 361370.). Both subscales consist of seven items that are answered on a four-point Likert scale ranging from 0 to three (Zigmond \& Snaith, 198364. Zigmond, A. S., \& Snaith, R. P. (1983). The hospital anxiety and depression scale. Acta Psychiatrica Scandinavica, 67, 361-370.). The HADS has demonstrated to be a valid screening tool for detecting symptoms of anxiety and depression (Bjelland, Dahl, Haug, \& Neckelmann, 20025. Bjelland, I., Dahl, A. A., Haug, T. T., \& Neckelmann, D. (2002). The validity of the hospital anxiety and depression scale. An updated literature review. Journal of Psychosomatic Research, 52, 69-77. doi:S0022399901002963 [pii]; Herrmann, 199723. Herrmann, C. (1997). International experiences with the Hospital Anxiety and Depression Scale - A review of validation data and clinical results. Journal of Psychosomatic Research, 42, 17-41. doi:S0022399996002164 [pii]) and has been shown to predict mortality in patients referred for exercise testing (Herrmann, Brand-Driehorst, Buss, \& Rüger, 200024. Herrmann, C., BrandDriehorst, S., Buss, U., \& Rüger, U. (2000). Effects of anxiety and depression on 5year mortality in 5057 patients referred for exercise testing. Journal of Psychosomatic Research, 48, 455-462. doi:10.1016/s0022-3999(99)00086-0). The internal consistency has been demonstrated previously with Cronbach's alpha of .83 for the anxiety subscale (HADS-A) and .82 for the depression subscale (HADS-D) (Bjelland et al., 20025. Bjelland, I., Dahl, A. A., Haug, T. T., \& Neckelmann, D. (2002). The validity of the hospital anxiety and depression scale. An updated literature review. Journal of Psychosomatic Research, 52, 69-77. doi:S0022399901002963 [pii]). In the current study, in the cohort of PCI patients, Cronbach's alphas were .85 for HADS-A and .81 for HADS-D, whereas in the cohort of CHF patients, Cronbach's alphas were .83 for HADS-A and .82 for HADSD. 
Damen, N.L., Versteeg, H., Helmondt, S.J. van, Jaegere, P.P. de, Geuns, R.J.M. van, Meine, M.M/m Domburg, R.T. van, Pedersen, S.S. The distressed (Type D) personality mediates the relationship between remembered parenting and psychological distress in cardiac patients Psychology \& Health: 2014, 29(3), 318-333

\section{Remembered parenting}

The Remembered Relationship with Parents $\left(\mathrm{RRP}^{10}\right)$ scale was used to retrospectively assess perceptions of parental care (Denollet et al., 200712. Denollet, J., Smolderen, K. G. E., van den Broek, K. C., \& Pedersen, S. S. (2007). The 10-item remembered relationship with parents (RRP10) scale: Two-factor model and association with adult depressive symptoms. Journal of Affective Disorders, 100, 179-189. doi:10.1016/j.jad.2006.10.009). This self-report instrument assesses caregiving processes with an emphasis on deficiencies in emphatic relationships between parents and child. Respondents are asked to describe the relationship with their parents while growing up, on a five-point Likert scale ranging from 0 (false) to 4 (true). The RRP ${ }^{10}$ consists of two subscales, Alienation from parents and Control by parents. Alienation refers to respondents' perception of dysfunctional communication and intimacy with their parents (e.g. I often felt that my parents did not understand me), while Control refers to the respondent's perception of an overprotective parenting style (e.g. I wished my parents would worry less about me). Remembered alienation and control were assessed with reference to the father and mother separately. However, in the current study, the combined score of both parents was used to assess Alienation and Control (score range [0-40]). A high score on both parenting scales indicate worse remembered parenting while growing up. Because of the non-pathological focus, the $\mathrm{RRP}^{10}$ is suitable for use in non-psychiatric populations and in epidemiological and clinical research (van den Broek et al., 201058. van den Broek, K. C., Smolderen, K. G., Pedersen, S. S., \& Denollet, J. (2010). Type D personality mediates the relationship between remembered parenting and perceived health. Psychosomatics, 51, 216-224. doi:10.1176/appi.psy.51.3.216). The RRP ${ }^{10}$ has a good factor structure, internal consistency (Cronbach's alpha $=.83-$ .86), and convergent validity with the Parenting Bonding Instrument (PBI) (Denollet et al., 200712. Denollet, J., Smolderen, K. G. E., van den Broek, K. C., \& Pedersen, $S$ S. (2007). The 10-item remembered relationship with parents (RRP10) scale: Twofactor model and association with adult depressive symptoms. Journal of Affective Disorders, 100, 179-189. doi:10.1016/j.jad.2006.10.009; Parker, Tupling, \& Brown, 197937. Parker, G., Tupling, H., \& Brown, L. B. (1979). A Parental Bonding Instrument. British Journal of Medical Psychology, 52, 1-10. doi:10.1111/j.20448341.1979.tb02487.x; van den Broek et al., 201058. van den Broek, K. C., Smolderen, K. G., Pedersen, S. S., \& Denollet, J. (2010). Type D personality mediates the relationship between remembered parenting and perceived health. Psychosomatics, 51, 216-224. doi:10.1176/appi.psy.51.3.216). In the current study, in the cohort of PCI patients, Cronbach's alpha was .90, whereas in the cohort of CHF patients, Cronbach's alpha was .89 .

\section{Statistical analyses}

Before investigating whether Type D personality, as represented by the interaction term of NA and SI, mediated the relationship between remembered parenting and anxiety and depression, we examined whether the assumptions underlying the mediation model according to Baron and Kenny (19864. Baron, R., \& Kenny, D. (1986). The moderator-mediator variable distinction in social psychological research: Conceptual, strategic, and statistical considerations. Journal of Personality and Social Psychology, 51, 1173-1182.) were fulfilled: (1) remembered 
Damen, N.L., Versteeg, H., Helmondt, S.J. van, Jaegere, P.P. de, Geuns, R.J.M. van, Meine, M.M/m Domburg, R.T. van, Pedersen, S.S. The distressed (Type D) personality mediates the relationship between remembered parenting and psychological distress in cardiac patients. Psychology \& Health: 2014, 29(3), 318-333

parenting had to be related to anxiety and depression; (2) remembered parenting had to be associated with the mediator Type D personality; and (3) Type D personality had to be associated with anxiety and depression, adjusted for remembered parenting (Figure 1). Type D personality was considered a mediator if it accounted for a significant part of the relation between remembered parenting and anxiety and depression (Baron \& Kenny, 19864. Baron, R., \& Kenny, D. (1986). The moderatormediator variable distinction in social psychological research: Conceptual, strategic, and statistical considerations. Journal of Personality and Social Psychology, 51, 1173-1182.). The assumptions for mediation were tested with a series of linear regression models. In general, with mediation, we mean that the direct effect of remembered parenting on psychological distress might be weakened by an indirect effect via Type D personality.

\section{[FIGURE 1]}

To allow for a more direct test of the mediation effect, Sobel tests were used (Sobel, 198254. Sobel, M. (1982). Asymptotic confidence intervals for indirect effects in structural equation models. Sociological Methodology, 13, 290-312.). Sobel tests, which are products of coefficient tests for the mediating variable effect, are used to test the significance of the mediating variable effect by dividing the estimate of the mediating variable effect by its standard error and comparing this value to a standard normal distribution. In contrast with causal step methods (e.g. the Baron and Kenny approach), Sobel tests are less prone to Type I errors and have more statistical power to detect mediation when present (MacKinnon, Lockwood, Hoffman, West, \& Sheets, 200229. MacKinnon, D., Lockwood, C., Hoffman, J., West, S., \& Sheets, V. (2002). A comparison of methods to test mediation and other intervening variable effects. Psychological Methods, 7, 83-104.). To further test the robustness of our mediation model bootstrapping, using 5000 sample replicates, was performed (Preacher \& Hayes, 200847. Preacher, K., \& Hayes, A. (2008). Asymptotic and resampling strategies for assessing and comparing indirect effects in multiple mediator models. Behavior Research Methods, 40, 879-891.

doi:10.3758/brm.40.3.879). Bootstrapping is especially suitable for small sample sizes and avoids the assumption that the indirect effects are normally distributed. Indirect effects are unstandardised coefficients, which are significant when the $95 \%$ confident interval does not contain zero.

In additional multivariable linear regression analyses, we examined whether Type D personality remained significantly associated with anxiety and depression, adjusting for socio-demographic and clinical variables. In the PCI cohort, we adjusted for all baseline characteristics listed in Table 1, except for aspirin as almost all patients (i.e. 95\%) were prescribed aspirin. In the CHF cohort, we adjusted for gender, age, NYHA functional class, LVEF, aetiology and diabetes mellitus. Covariates were selected a priori based on the literature (Babyak, 20043. Babyak, M. A. (2004). What you see may not be what you get: A brief, nontechnical introduction to overfitting in regression-type models. Psychosomatic Medicine, 66, 411-421.

doi:10.1097/01.psy.0000127692.23278.a9; Freedland et al., 200518. Freedland, K. E., Babyak, M. A., McMahon, R. J., Jennings, J. R., Golden, R. N., \& Sheps, D. S. (2005). Statistical guidelines for psychosomatic medicine. Psychosomatic Medicine, 67, 167. doi:10.1097/01.psy.0000157600.76469.9a; Peduzzi, Concato, Kemper, 
Damen, N.L., Versteeg, H., Helmondt, S.J. van, Jaegere, P.P. de, Geuns, R.J.M. van, Meine, M.M/m Domburg, R.T. van, Pedersen, S.S. The distressed (Type D) personality mediates the relationship between remembered parenting and psychological distress in cardiac patients 7 Psychology \& Health: 2014, 29(3), 318-333

Holford, \& Feinstein, 199644. Peduzzi, P., Concato, J., Kemper, E., Holford, T. R., \& Feinstein, A. R. (1996). A simulation study of the number of events per variable in logistic regression analysis. Journal of Clinical Epidemiology, 49, 1373-1379. doi:10.1016/S0895-4356(96)00236-3). The assumption of multicollinearity was checked for all separate multivariable linear regression models.

\section{[TABLE 1]}

Sobel tests and bootstrapping were performed with SPSS macros by Preacher and Hayes (Preacher \& Hayes, 200446. Preacher, K., \& Hayes, A. (2004). SPSS and SAS procedures for estimating indirect effects in simple mediation models. Behavior Research Methods, 36, 717-731. doi:10.3758/bf03206553, 200847. Preacher, K., \& Hayes, A. (2008). Asymptotic and resampling strategies for assessing and comparing indirect effects in multiple mediator models. Behavior Research Methods, 40, 879891. doi:10.3758/brm.40.3.879), as SPSS does not provide the possibility to directly test the mediation effect. For all other analyses, SPSS for Windows version 17.0 was used.

\section{RESULTS}

\section{Characteristics of PCI patients}

Of the 869 eligible patients treated with PCI in the study period, 29 died within 4 weeks. The remaining 840 were asked to participate in the study, of which 297 did not return the questionnaire at baseline (64.6\% response rate). Of the remaining 543 patients, 108 patients did not complete the HADS, DS14, or RRP ${ }^{10}$. Final analyses were based on data from 435 patients $(77.5 \%$ men; mean age: $62.6 \pm 10.7$ years, range [30-91] years). In the current study, the mean scores for NA and SI were $8.2 \pm$ 6.2 and $9.1 \pm 6.4$, respectively. Patient characteristics for the total sample of PCI patients are presented in Table 1.

\section{Characteristics of CHF patients}

Of the 182 eligible patients implanted with a CRT-D in the study period, 35 refused to participate and 8 patients did not return the questionnaire at baseline $(76.4 \%$ response rate). Of the remaining 139 patients, 16 patients did not complete the HADS, DS14, or RPP ${ }^{10}$. Final analyses were based on 123 patients $(71.5 \%$ men; mean age: $65.3 \pm 10.5$ years, range [30-84] years). In the current study, the mean scores for NA and SI were $8.4 \pm 6.4$ and $9.1 \pm 5.8$, respectively. Patient characteristics for the total sample of CHF patients are presented in Table 1.

\section{Type D, parenting and distress in PCI patients}

In PCI patients, we tested the hypothesis that Type D personality mediated the relationship between remembered parenting and anxiety and depression, using a series of linear regression analysis. Results indicated that parental alienation and control were associated with both more anxiety $(p \leq .001)$ and depression $(p \leq .001)$ (Table 2). The second assumption underlying the mediation model was also fulfilled: Parental alienation and control were significantly related to Type D personality $(p \leq$ 
Damen, N.L., Versteeg, H., Helmondt, S.J. van, Jaegere, P.P. de, Geuns, R.J.M. van, Meine, M.M/m Domburg, R.T. van, Pedersen, S.S. The distressed (Type D) personality mediates the relationship between remembered parenting and psychological distress in cardiac patients Psychology \& Health: 2014, 29(3), 318-333

.001) (Table 2). Multivariable linear regression analysis showed that Type D personality was significantly associated with both higher anxiety $(p \leq .001)$ and depression $(p \leq .001)$, when adjusting for remembered Alienation and Control (Table $2)$. Once Type D personality was included in the model, the effect of the Remembered Relationship with Parents on anxiety and depression was no longer significant, indicating mediation.

\section{[TABLE 2]}

Sobel tests confirmed that Type D personality significantly mediated the relationship between remembered parenting and anxiety $\left(z^{\prime}=7.58, p<.001\right.$ for Alienation, and $z^{\prime}$ $=6.88, p<.001$ for Control, respectively) and depression $\left(z^{\prime}=7.20, p<.001\right.$ for Alienation, and $z^{\prime}=6.47, p<.001$ for Control, respectively). In addition, bootstrapping further confirmed the mediation model with significant indirect effects of Type D personality on the relationship between remembered parenting and anxiety (indirect effect $=.08, \mathrm{SE}=.01,95 \% \mathrm{CI}[.06-.12]$ for Alienation, and indirect effect $=$ $.08, \mathrm{SE}=.01,95 \% \mathrm{CI}[.06-.11]$ for Control, respectively) and depression (indirect effect $=.09, \mathrm{SE}=.01,95 \% \mathrm{CI}[.06-.12]$ for Alienation, and indirect effect $=.08, \mathrm{SE}$ $=.01,95 \%$ CI [.06-.11] for Control, respectively).

In extended multivariable linear regression analyses, Type $D$ personality remained significantly associated with higher levels of anxiety and depression $(\beta=.56, p \leq$ $.001, \Delta R^{2}=.26$ and $\beta=.54, p<.001, \Delta R^{2}=.24$, respectively), adjusting for sociodemographic and clinical variables. Female gender $(\beta=.11, p=.002)$ and diabetes mellitus $(\beta=.09, p=.038)$ were associated with higher levels of anxiety, whereas higher age $(\beta=.12, p=.007)$, diabetes mellitus $(\beta=.11, p=.020)$, and smoking $(\beta=$ $.12, p=.014)$ were associated with higher levels of depression. In all multivariable linear regression models, the assumption of multicollinearity was met.

\section{Type D, parenting and distress in CHF patients}

In CHF patients, parental alienation and control were significantly associated with more anxiety $(p \leq .001)$ and depression $(p \leq .01)$ (Table 2$)$. Parental alienation and control were also significantly related to Type D personality $(p \leq .001)$ (Table 2$)$. Once again, Type D personality was significantly associated with both higher anxiety $(p \leq .001)$ and depression $(p \leq .001)$ when adjusted for parental Alienation and Control (Table 3). Once Type D personality was included in the model, the effect of remembered parenting on anxiety and depression was no longer significant, indicating mediation.

\section{[TABLE 3]}

Sobel tests confirmed that Type D mediated the relationship between remembered parenting and anxiety $(z=3.67, p \leq .001$ for Alienation, and $z=3.37, p \leq .001$ for Control, respectively) and depression ( $z=3.67, p \leq .001$ for Alienation, and $z=3.58$, $p \leq .001$ for Control, respectively). In addition, bootstrapping further confirmed the mediation model with significant indirect effects of Type D personality on the relationship between remembered parenting and anxiety (indirect effect $=10, \mathrm{SE}=$ $.03,95 \% \mathrm{CI}[.05-.15]$ for Alienation, and indirect effect $=.09, \mathrm{SE}=.03,95 \% \mathrm{CI}$ 
Damen, N.L., Versteeg, H., Helmondt, S.J. van, Jaegere, P.P. de, Geuns, R.J.M. van, Meine, M.Mm Domburg, R.T. van, Pedersen, S.S. The distressed (Type D) personality mediates the relationship between remembered parenting and psychological distress in cardiac patients Psychology \& Health: 2014, 29(3), 318-333

[.04-.16] for Control, respectively) and depression (indirect effect $=.11, \mathrm{SE}=.02$, $95 \%$ CI [.07-.16] for Alienation, and indirect effect $=.11, \mathrm{SE}=.04,95 \%$ CI $[.05-$ .18] for Control, respectively).

In extended multivariable regression analyses, Type $\mathrm{D}$ personality remained significantly associated with higher levels of anxiety and depression $(\beta=.45, p \leq$ $.001, \Delta R^{2}=.16$ and $\beta=.57, p \leq .001, \Delta R^{2}=.26$, respectively), adjusting for remembered parenting, age, gender, NYHA functional class, LVEF, aetiology, and diabetes. None of the socio-demographic and clinical variables were significantly associated with anxiety, whereas higher NYHA functional class was associated with higher levels of depression $(\beta=.25, p=.002)$. In all multivariable linear regression models, the assumption of multicollinearity was met.

\section{Discussion}

To our knowledge, this is the first study to report on the role of Type D personality as a mediator between remembered parenting and anxiety and depression in cardiac patients. In both PCI and CHF patients, remembered dysfunctional parenting was significantly associated with higher anxiety and depression levels, as well as with Type D personality. In multivariable linear regression analyses, Type D personality accounted for $25-29 \%$ of the variance in anxiety and $23-46 \%$ of the variance in depression, while remembered parenting was no longer significantly associated with any of these symptoms. Sobel tests and bootstrapping confirmed the finding that Type D personality mediated the relationship between remembered parenting and anxiety and depression in both PCI and CHF patients.

The current study corroborates the findings of previous studies, demonstrating that personality factors may mediate the relationship between parenting styles and depression (Avagianou \& Zafiropoulou, 20082. Avagianou, P., \& Zafiropoulou, $M$. (2008). Parental bonding and depression: Personality as a mediating factor. International Journal of Adolescent Medicine and Health, 20, 261-269.; Enns et al., 200015. Enns, M. W., Cox, B. J., \& Larsen, D. K. (2000). Perceptions of parental bonding and symptom severity in adults with depression: Mediation by personality dimensions. Canadian Journal of Psychiatry. Revue Canadienne de Psychiatrie, 45, 263-268.; Parker, 199336. Parker, G. (1993). Parental rearing style: Examining for links with personality vulnerability factors for depression. Social Psychiatry and Psychiatric Epidemiology, 28, 97-100. doi:10.1007/bf00801738). In line with a recent study in the general Dutch population, we found that Type D personality mediated the relationship between remembered parenting and psychological distress (van den Broek et al., 201058. van den Broek, K. C., Smolderen, K. G., Pedersen, S. $S ., \&$ Denollet, J. (2010). Type D personality mediates the relationship between remembered parenting and perceived health. Psychosomatics, 51, 216-224. doi:10.1176/appi.psy.51.3.216). However, the current study extends previous research by showing that this mediation model is also applicable to cardiac patients. A paucity of studies have examined the association between parenting styles and personality development, showing that dysfunctional parenting styles, like overprotection and coldness, are related to the development of for example neuroticism (Furukawa, 199219. Furukawa, T. (1992). Perceived parental rearing, personality and mental status in Japanese adolescents. Journal of Adolescence, 15, 317-322. doi:10.1016/0140-1971(92)90033-2; McCrae \& Costa, 198831. McCrae, 
Damen, N.L., Versteeg, H., Helmondt, S.J. van, Jaegere, P.P. de, Geuns, R.J.M. van, Meine, M.M/m Domburg, R.T. van, Pedersen, S.S. The distressed (Type D) personality mediates the relationship between remembered parenting and psychological distress in cardiac patients Psychology \& Health: 2014, 29(3), 318-333

R. R., \& Costa, P. T. (1988). Recalled parent-child relations and adult personality. Journal of Personality, 56, 417-434. doi:10.1111/j.1467-6494.1988.tb00894.x; Reti et al., 200249. Reti, I. M., Samuels, J. F., Eaton, W. W., Bienvenu, O. J., Costa, P. T., \& Nestadt, G. (2002). Influences of parenting on normal personality traits. Psychiatry Research, 111, 55-64. doi:10.1016/s0165-1781(02)00128-2) and NA (Aron et al., 20051. Aron, E. N., Aron, A., \& Davies, K. M. (2005). Adult shyness: The interaction of temperamental sensitivity and an adverse childhood environment. Personality and Social Psychology Bulletin, 31, 181-197. doi:10.1177/0146167204271419). This is the first study to show that there is a link between remembered parenting and Type $\mathrm{D}$ personality in cardiac patients, with Type D patients reporting significantly more alienation from and control by parents than non-Type D patients. Given that Type D personality has been associated with a 2 -fold increased risk of poor physical and mental health status and a more than 3-fold increased risk of poor prognosis in CAD (Denollet et al., 201011. Denollet, J., Schiffer, A. A., \& Spek, V. (2010). A general propensity to psychological distress affects cardiovascular outcomes. Circulation: Cardiovascular Quality and Outcomes, 3, 546-557. doi:10.1161/circoutcomes.109.934406; Versteeg et al., 201160. Versteeg, H., Spek, V., Pedersen, S. S., \& Denollet, J. (2011). Type D personality and health status in cardiovascular disease populations: A meta-analysis of prospective studies. European Journal of Cardiovascular Prevention \& Rehabilitation, 19, 1373-1380. doi:10.1177/1741826711425338), future longitudinal studies are warranted to examine whether dysfunctional parenting styles may contribute to the development of Type D personality.

Information on genetic and environmental factors that contribute to the development of Type D personality is important for developing appropriate intervention trials that target this personality disposition in patients with established cardiovascular disease. To our knowledge, only one recent psychological intervention trial in Dutch community residents specifically targeted Type D personality. In this study, a mindfulness-based stress reduction intervention was designed to reduce the NA and SI characteristics of Type D personality. After the 8-week intervention, the intervention group showed a significant decrease in both NA and SI dimensions, although change in Type D caseness did not differ between groups (Nyklicek, van Beugen, \& Denollet, 201235. Nyklicek, I., van Beugen, S., \& Denollet, J. (2012). Effects of mindfulness-based stress reduction on distressed (Type D) personality traits: A randomized controlled trial. Journal of Behavioral Medicine, 36, 361-370. doi:10.1007/s 10865-012-9431-3). In post-MI patients, a psychological intervention trial has been planned to evaluate the effect of short-term psychotherapy on incident CAD and levels of psychological distress, including Type D personality (Roncella et al., 200950. Roncella, A., Giornetti, A., Cianfrocca, C., Pasceri, V., Pelliccia, F., \& Denollet, J. (2009). Rationale and trial design of a randomized, controlled study on short-term psychotherapy after acute myocardial infarction: The STEP-IN-AMI trial (short term psychotherapy in acute myocardial infarction). Journal of Cardiovascular Medicine, 10, 947-452. doi:10.2459/JCM.0b013e32832fb477). Results of the current study suggest that when designing a behavioural intervention for Type D patients, it may also be important to take remembered parenting into account.

The limitations of the current study must be acknowledged. First, the cross-sectional study design does not allow for causal inferences about the relationship between 
Damen, N.L., Versteeg, H., Helmondt, S.J. van, Jaegere, P.P. de, Geuns, R.J.M. van, Meine, M.M/m Domburg, R.T. van, Pedersen, S.S. The distressed (Type D) personality mediates the relationship between remembered parenting and psychological distress in cardiac patients Psychology \& Health: 2014, 29(3), 318-333

remembered parenting, Type D personality, and anxiety and depression. A so-called recall bias may arise, as it is possible that childhood memories are influenced by the patient's personality and current feelings of distress. For example, given the high levels of SI in Type D patients, these patients may report that they feel more alienated from their parents, as compared with patients with lower levels of SI. This should be investigated further. Second, patients who indicated that there was only maternal or paternal parenting were excluded from the analyses. This was the case in $7.7 \%$ (42/543) of PCI patients and 10.1\% (14/139) of CHF patients. Third, data on Type D personality and anxiety and depression were obtained from self-report questionnaires, and therefore, common method variance may have contributed to the significant results. However, we only used validated and reliable questionnaires to assess the psychological constructs studied, which have been used frequently in different cardiovascular patient groups (Haworth, Moniz-Cook, Clark, Wang, \& Cleland, 200722. Haworth, J. E., Moniz-Cook, E., Clark, A. L., Wang, M., \& Cleland, J. G. F. (2007). An evaluation of two self-report screening measures for mood in an out-patient chronic heart failure population. International Journal of Geriatric Psychiatry, 22, 1147-1153. doi:10.1002/gps.1807; Pedersen et al., 200642. Pedersen, S. S., Ong, A. T. L., Sonnenschein, K., Serruys, P. W., Erdman, R. A. M., \& van Domburg, R. T. (2006). Type D personality and diabetes predict the onset of depressive symptoms in patients after percutaneous coronary intervention. American Heart Journal, 151, 367.e361-367.e366. doi: 10.1016/j.ahj.2005.08.012

Finally, in contrast to the current study, previous studies mainly used the PBI to assess remembered parenting, rather than the RRP ${ }^{10}$. However, it has been shown that the RRP ${ }^{10}$ has good convergent validity with the PBI (Denollet et al., 200712. Denollet, J., Smolderen, K. G. E., van den Broek, K. C., \& Pedersen, S. S. (2007). The 10-item remembered relationship with parents (RRP10) scale: Two-factor model and association with adult depressive symptoms. Journal of Affective Disorders, 100, 179-189. doi:10.1016/j.jad.2006.10.009; Parker et al., 197937. Parker, G., Tupling, H., \& Brown, L. B. (1979). A Parental Bonding Instrument. British Journal of Medical Psychology, 52, 1-10. doi:10.1111/j.2044-8341.1979.tb02487.x; van den Broek et al., 201058. van den Broek, K. C., Smolderen, K. G., Pedersen, S. S., \& Denollet, J. (2010). Type D personality mediates the relationship between remembered parenting and perceived health. Psychosomatics, 51, 216-224. doi:10.1176/appi.psy.51.3.216).

In conclusion, the current study showed that Type D personality mediated the relationship between remembered parenting and anxiety and depression in patients treated with PCI and CHF patients. Hence, in psychological intervention trials targeting Type D personality, it may be important to address remembered parenting. Future studies using a longitudinal design are warranted to examine the directionality of the relationship between remembered parenting, Type D personality and psychological distress in cardiac patients.

\section{FUNDING}

This research was supported with a VIDI grant (91710393) to Prof. Susanne S. Pedersen from The Netherlands Organization for Health Research and Development (ZonMW), The Hague, the Netherlands. 
Damen, N.L., Versteeg, H., Helmondt, S.J. van, Jaegere, P.P. de, Geuns, R.J.M. van, Meine, M.M/m Domburg, R.T. van, Pedersen, S.S. The distressed (Type D) personality mediates the relationship between remembered parenting and psychological distress in cardiac patients Psychology \& Health: 2014, 29(3), 318-333

\section{NOTES}

Notes: ${ }^{a}$ Results are presented as $n(\%)$ unless otherwise stated.

${ }^{\mathrm{b}}$ Previous myocardial infarction (MI), percutaneous coronary intervention (PCI) or coronary artery bypass graft surgery $(\mathrm{CABG})$.

$\mathrm{BMI}=$ Body mass index $\left(\mathrm{kg} / \mathrm{m}^{2}\right), \mathrm{CAD}=$ Coronary artery disease, CRT-D $=$ cardiac resynchronization therapy defibrillator, $\mathrm{LVEF}=$ Left ventricular ejection fraction, NYHA $=$ New York Heart Association.

\section{REFERENCES}

1. Aron, E. N., Aron, A., \& Davies, K. M. (2005). Adult shyness: The interaction of temperamental sensitivity and an adverse childhood environment. Personality and Social Psychology Bulletin, 31, 181-197. doi:10.1177/0146167204271419

2. Avagianou, P., \& Zafiropoulou, M. (2008). Parental bonding and depression: Personality as a mediating factor. International Journal of Adolescent Medicine and Health, 20, 261269.

3. Babyak, M. A. (2004). What you see may not be what you get: A brief, nontechnical introduction to overfitting in regression-type models. Psychosomatic Medicine, 66, 411 421. doi:10.1097/01.psy.0000127692.23278.a9

4. Baron, R., \& Kenny, D. (1986). The moderator-mediator variable distinction in social psychological research: Conceptual, strategic, and statistical considerations. Journal of Personality and Social Psychology, 51, 1173-1182.

5. Bjelland, I., Dahl, A. A., Haug, T. T., \& Neckelmann, D. (2002). The validity of the hospital anxiety and depression scale. An updated literature review. Journal of Psychosomatic Research, 52, 69-77. doi:S0022399901002963 [pii]

6. Conraads, V. M., Denollet, J., De Clerck, L. S., Stevens, W. J., Bridts, C., \& Vrints, C. J. (2006). Type D personality is associated with increased levels of tumour necrosis factor (TNF)- $\alpha$ and TNF- $\alpha$ receptors in chronic heart failure. International Journal of Cardiology, 113, 34-38. doi:10.1016/j.ijcard.2005.10.013

7. Denollet, J. (2005). DS14: Standard assessment of negative affectivity, social inhibition, and Type D personality. Psychosomatic Medicine, 67, 89-97. doi:10.1097/01.psy.0000149256.81953.49

8. Denollet, J., Conraads, V. M., Brutsaert, D. L., De Clerck, L. S., Stevens, W. J., \& Vrints, C. J. (2003). Cytokines and immune activation in systolic heart failure: The role of Type D personality. Brain, Behavior, and Immunity, 17, 304-309. doi:10.1016/s08891591(03)00060-6

9. Denollet, J., Pedersen, S. S., Ong, A. T., Erdman, R. A., Serruys, P. W., \& van Domburg, R. T. (2006). Social inhibition modulates the effect of negative emotions on cardiac prognosis following percutaneous coronary intervention in the drug-eluting stent era. European Heart Journal, 27, 171-177. doi:ehi616 [pii]10.1093/eurheartj/ehi616

10. Denollet, J., Pedersen, S. S., Vrints, C. J., \& Conraads, V. M. (2006). Usefulness of Type $D$ personality in predicting five-year cardiac events above and beyond concurrent symptoms of stress in patients with coronary heart disease. The American Journal of Cardiology, 97, 970-973. doi:10.1016/j.amjcard.2005.10.035

11. Denollet, J., Schiffer, A. A., \& Spek, V. (2010). A general propensity to psychological distress affects cardiovascular outcomes. Circulation: Cardiovascular Quality and Outcomes, 3, 546-557. doi:10.1161/circoutcomes.109.934406

12. Denollet, J., Smolderen, K. G. E., van den Broek, K. C., \& Pedersen, S. S. (2007). The 10-item remembered relationship with parents (RRP10) scale: Two-factor model and association with adult depressive symptoms. Journal of Affective Disorders, 100, 179-189. doi:10.1016/j.jad.2006.10.009

13. Dong, M., Giles, W. H., Felitti, V. J., Dube, S. R., Williams, J. E., \& Chapman, D. P. (2004). Insights into causal pathways for ischemic heart disease: Adverse childhood experiences study. Circulation, 110, 1761-1766. doi:10.1161/01.cir.0000143074.54995.7f 
Damen, N.L., Versteeg, H., Helmondt, S.J. van, Jaegere, P.P. de, Geuns, R.J.M. van, Meine, M.M/m Domburg, R.T. van, Pedersen, S.S. The distressed (Type D) personality mediates the relationship between remembered parenting and psychological distress in cardiac patients Psychology \& Health: 2014, 29(3), 318-333

14. Emons, W. H. M., Meijer, R. R., \& Denollet, J. (2007). Negative affectivity and social inhibition in cardiovascular disease: Evaluating Type-D personality and its assessment using item response theory. Journal of Psychosomatic Research, 63, 27-39. doi:10.1016/j.jpsychores.2007.03.010

15. Enns, M. W., Cox, B. J., \& Larsen, D. K. (2000). Perceptions of parental bonding and symptom severity in adults with depression: Mediation by personality dimensions. Canadian Journal of Psychiatry. Revue Canadienne de Psychiatrie, 45, 263-268.

16. Felitti, V. J., Anda, R. F., Nordenberg, D., Williamson, D. F., Spitz, A. M., \& Edwards, V. (1998). Relationship of childhood abuse and household dysfunction to many of the leading causes of death in adults: The adverse childhood experiences (ACE) Study. American Journal of Preventive Medicine, 14, 245-258. doi:10.1016/s0749-3797(98)00017-8

17. Ferguson, E., Williams, L., O'Connor, R. C., Howard, S., Hughes, B. M., \& Johnston, D. W. (2009). A taxometric analysis of Type-D personality. Psychosomatic Medicine, 71, 981986. doi:10.1097/PSY.0b013e3181bd888b

18. Freedland, K. E., Babyak, M. A., McMahon, R. J., Jennings, J. R., Golden, R. N., \& Sheps, D. S. (2005). Statistical guidelines for psychosomatic medicine. Psychosomatic Medicine, 67, 167. doi:10.1097/01.psy.0000157600.76469.9a

19. Furukawa, T. (1992). Perceived parental rearing, personality and mental status in Japanese adolescents. Journal of Adolescence, 15, 317-322. doi:10.1016/01401971(92)90033-2

20. Goodyear, M. D. E., Krleza-Jeric, K., \& Lemmens, T. (2007). The Declaration of Helsinki. BMJ, 335, 624-625. doi:10.1136/bmj.39339.610000.BE

21. Habra, M. E., Linden, W., Anderson, J. C., \& Weinberg, J. (2003). Type D personality is related to cardiovascular and neuroendocrine reactivity to acute stress. Journal of Psychosomatic Research, 55, 235-245. doi:10.1016/s0022-3999(02)00553-6

22. Haworth, J. E., Moniz-Cook, E., Clark, A. L., Wang, M., \& Cleland, J. G. F. (2007). An evaluation of two self-report screening measures for mood in an out-patient chronic heart failure population. International Journal of Geriatric Psychiatry, 22, 1147-1153. doi:10.1002/gps.1807

23. Herrmann, C. (1997). International experiences with the Hospital Anxiety and Depression Scale $-A$ review of validation data and clinical results. Journal of Psychosomatic Research, 42, 17-41. doi:S0022399996002164 [pii]

24. Herrmann, C., Brand-Driehorst, S., Buss, U., \& Rüger, U. (2000). Effects of anxiety and depression on 5-year mortality in 5057 patients referred for exercise testing. Journal of Psychosomatic Research, 48, 455-462. doi:10.1016/s0022-3999(99)00086-0

25. Huis in 't Veld, E. M. J., Vingerhoets, A. J. J. M., \& Denollet, J. (2011). Attachment style and self-esteem: The mediating role of Type $D$ personality. Personality and Individual Differences, 50, 1099-1103. doi:10.1016/j.paid.2011.01.034

26. Kendler, K. S., Myers, J., \& Prescott, C. A. (2000). Parenting and adult mood, anxiety and substance use disorders in female twins: An epidemiological, multi-informant, retrospective study. Psychological Medicine, 30, 281-294.

27. Kupper, N., Boomsma, D. I., de Geus, E. J. C., Denollet, J., \& Willemsen, G. (2011). Nine-year stability of Type $D$ personality: Contributions of genes and environment. Psychosomatic Medicine, 73, 75-82. doi:10.1097/PSY.0b013e3181fdce54

28. Lee, A., \& Hankin, B. L. (2009). Insecure attachment, dysfunctional attitudes, and low self-esteem predicting prospective symptoms of depression and anxiety during adolescence. Journal of Clinical Child \& Adolescent Psychology, 38, 219-231. doi:10.1080/15374410802698396

29. MacKinnon, D., Lockwood, C., Hoffman, J., West, S., \& Sheets, V. (2002). A comparison of methods to test mediation and other intervening variable effects. Psychological Methods, 7, 83-104.

30. Martens, E. J., Mols, F., Burg, M. M., \& Denollet, J. (2010). Type D personality predicts clinical events after myocardial infarction, above and beyond disease severity and depression. Journal of Clinical Psychiatry, 71, 778-783.

31. McCrae, R. R., \& Costa, P. T. (1988). Recalled parent-child relations and adult personality. Journal of Personality, 56, 417-434. doi:10.1111/j.1467-6494.1988.tb00894.x 
Damen, N.L., Versteeg, H., Helmondt, S.J. van, Jaegere, P.P. de, Geuns, R.J.M. van, Meine, M.M/m Domburg, R.T. van, Pedersen, S.S. The distressed (Type D) personality mediates the relationship between remembered parenting and psychological distress in cardiac patients. Psychology \& Health: 2014, 29(3), 318-333

32. Molloy, G. J., Perkins-Porras, L., Strike, P. C., \& Steptoe, A. (2008). Type-D Personality and cortisol in survivors of acute coronary syndrome. Psychosomatic Medicine, 70, 863868. doi:10.1097/PSY.0b013e3181842e0c

33. Mols, F., Martens, E. J., \& Denollet, J. (2010). Type D personality and depressive symptoms are independent predictors of impaired health status following acute myocardial infarction. Heart, 96, 30-35. doi:10.1136/hrt.2009.170357

34. Neale, M. C., Walters, E., Heath, A. C., Kessler, R. C., Pérusse, D., \& Eaves, L. J. (1994). Depression and parental bonding: Cause, consequence, or genetic covariance? Genetic Epidemiology, 11, 503-522. doi:10.1002/gepi.1370110607

35. Nyklicek, I., van Beugen, S., \& Denollet, J. (2012). Effects of mindfulness-based stress reduction on distressed (Type $D$ ) personality traits: A randomized controlled trial. Journal of Behavioral Medicine, 36, 361-370. doi:10.1007/s10865-012-9431-3

36. Parker, G. (1993). Parental rearing style: Examining for links with personality vulnerability factors for depression. Social Psychiatry and Psychiatric Epidemiology, 28, 97-100. doi:10.1007/bf00801738

37. Parker, G., Tupling, H., \& Brown, L. B. (1979). A Parental Bonding Instrument. British Journal of Medical Psychology, 52, 1-10. doi:10.1111/j.2044-8341.1979.tb02487.x

[CrossRef], [Web of Science ${ }^{\circledR}$ ], [CSA]

38. Pedersen, S. S., \& Denollet, J. (2006). Is Type D personality here to stay? Emerging evidence across cardiovascular-disease patient groups. Current Cardiology Reviews, 2, 205-213.

39. Pedersen, S. S., Denollet, J., Ong, A. T., Sonnenschein, K., Erdman, R. A., \& Serruys, P. W. (2007). Adverse clinical events in patients treated with sirolimus-eluting stents: The impact of Type D personality. European Journal of Cardiovascular Prevention and Rehabilitation, 14, 135-140. doi:10.1097/HJR.0b013e328045c282 00149831-20070200000020 [pii]

40. Pedersen, S. S., Denollet, J., Ong, A. T. L., Serruys, P. W., Erdman, R. A. M., \& van Domburg, R. T. (2007). Impaired health status in Type D patients following PCl in the drugeluting stent era. International Journal of Cardiology, 114, 358-365.

doi:10.1016/j.ijcard.2005.12.018

41. Pedersen, S. S., Lemos, P. A., van Vooren, P. R., Liu, T. K. K., Daemen, J., \& Erdman, R. A. M. (2004). Type D personality predicts death or myocardial infarction after bare metal stent or sirolimus-eluting stent implantation: A rapamycin-eluting stent evaluated at rotterdam cardiology hospital (RESEARCH) registry substudy. Journal of the American College of Cardiology, 44, 997-1001. doi:10.1016/j.jacc.2004.05.064

42. Pedersen, S. S., Ong, A. T. L., Sonnenschein, K., Serruys, P. W., Erdman, R. A. M., \& van Domburg, R. T. (2006). Type D personality and diabetes predict the onset of depressive symptoms in patients after percutaneous coronary intervention. American Heart Journal, 151, 367.e361-367.e366. doi: 10.1016/j.ahj.2005.08.012

43. Pedersen, S. S., van Domburg, R. T., Theuns, D. A. M. J., Jordaens, L., \& Erdman, R. A. M. (2004). Type $D$ personality is associated with increased anxiety and depressive symptoms in patients with an implantable cardioverter defibrillator and their partners. Psychosomatic Medicine, 66, 714-719. doi:10.1097/01.psy.0000132874.52202.21

44. Peduzzi, P., Concato, J., Kemper, E., Holford, T. R., \& Feinstein, A. R. (1996). A simulation study of the number of events per variable in logistic regression analysis. Journal of Clinical Epidemiology, 49, 1373-1379. doi:10.1016/S0895-4356(96)00236-3

45. Poston, W. S. C., Haddock, C. K., Conard, M. W., Jones, P., \& Spertus, J. (2003). Assessing depression in the cardiac patient. Behavior Modification, 27, 26-36. doi:10.1177/0145445502238691

46. Preacher, K., \& Hayes, A. (2004). SPSS and SAS procedures for estimating indirect effects in simple mediation models. Behavior Research Methods, 36, 717-731. doi:10.3758/bf03206553

47. Preacher, K., \& Hayes, A. (2008). Asymptotic and resampling strategies for assessing and comparing indirect effects in multiple mediator models. Behavior Research Methods,

40, 879-891. doi:10.3758/brm.40.3.879 [CrossRef], [PubMed], [Web of Science ${ }^{\circledR}$ ] 
Damen, N.L., Versteeg, H., Helmondt, S.J. van, Jaegere, P.P. de, Geuns, R.J.M. van, Meine, M.M/m Domburg, R.T. van, Pedersen, S.S. The distressed (Type D) personality mediates the relationship between remembered parenting and psychological distress in cardiac patients Psychology \& Health: 2014, 29(3), 318-333

48. Rapee, R. M. (1997). Potential role of childrearing practices in the development of anxiety and depression. Clinical Psychology Review, 17, 47-67. doi:10.1016/s02727358(96)00040-2

49. Reti, I. M., Samuels, J. F., Eaton, W. W., Bienvenu, O. J., Costa, P. T., \& Nestadt, G. (2002). Influences of parenting on normal personality traits. Psychiatry Research, 111, 5564. doi:10.1016/s0165-1781(02)00128-2

50. Roncella, A., Giornetti, A., Cianfrocca, C., Pasceri, V., Pelliccia, F., \& Denollet, J. (2009). Rationale and trial design of a randomized, controlled study on short-term psychotherapy after acute myocardial infarction: The STEP-IN-AMI trial (short term psychotherapy in acute myocardial infarction). Journal of Cardiovascular Medicine, 10, 947-452. doi:10.2459/JCM.0b013e32832fb477

51. Russek, L. G., \& Schwartz, G. E. (1997). Perceptions of parental caring predict health status in midlife: A 35-year follow-up of the Harvard mastery of stress study.

Psychosomatic Medicine, 59, 144-149.

52. Schiffer, A. A., Denollet, J., Widdershoven, J. W., Hendriks, E. H., \& Smith, O. R. F. (2007). Failure to consult for symptoms of heart failure in patients with a type-D personality. Heart, 93, 814-818. doi:10.1136/hrt.2006.102822

53. Schiffer, A. A., Pedersen, S. S., Widdershoven, J. W., Hendriks, E. H., Winter, J. B., \& Denollet, J. (2005). The distressed (type D) personality is independently associated with impaired health status and increased depressive symptoms in chronic heart failure. European Journal of Cardiovascular Prevention \& Rehabilitation, 12, 341-346. doi:10.1097/01.hjr.0000173107.76109.6c

54. Sobel, M. (1982). Asymptotic confidence intervals for indirect effects in structural equation models. Sociological Methodology, 13, 290-312.

55. Spindler, H., Pedersen, S. S., Serruys, P. W., Erdman, R. A. M., \& van Domburg, R. T. (2007). Type-D personality predicts chronic anxiety following percutaneous coronary intervention in the drug-eluting stent era. Journal of Affective Disorders, 99, 173-179. doi:10.1016/j.jad.2006.09.009

56. Spinhoven, P., Ormel, J., Sloekers, P. P., Kempen, G. I., Speckens, A. E., \& Van Hemert, A. M. (1997). A validation study of the Hospital Anxiety and Depression Scale (HADS) in different groups of Dutch subjects. Psychological Medicine, 27, 363-370.

57. Steptoe, A., \& Molloy, G. J. (2007). Personality and heart disease. Heart, 93, 783-784. doi:10.1136/hrt.2006.109355

58. van den Broek, K. C., Smolderen, K. G., Pedersen, S. S., \& Denollet, J. (2010). Type D personality mediates the relationship between remembered parenting and perceived health. Psychosomatics, 51, 216-224. doi:10.1176/appi.psy.51.3.216 [CrossRef],

[PubMed]

59. van Gestel, Y. R. B. M., Pedersen, S. S., van de Sande, M., de Jaegere, P. P. T., Serruys, P. W., \& Erdman, R. A. M. (2007). Type-D personality and depressive symptoms predict anxiety 12 months post-percutaneous coronary intervention. Journal of Infectious

Diseases, 103, 197-203.

60. Versteeg, H., Spek, V., Pedersen, S. S., \& Denollet, J. (2011). Type D personality and health status in cardiovascular disease populations: A meta-analysis of prospective studies. European Journal of Cardiovascular Prevention \& Rehabilitation, 19, 1373-1380. doi:10.1177/1741826711425338

61. Whitehead, D. L., Perkins-Porras, L., Strike, P. C., Magid, K., \& Steptoe, A. (2007). Cortisol awakening response is elevated in acute coronary syndrome patients with type-D personality. Journal of Psychosomatic Research, 62, 419-425.

http://dx.doi.org.proxy.library.uu.nl/10.1016/j.jpsychores.2006.11.005

62. Williams, L., O'Carroll, R. E., \& O'Connor, R. C. (2009). Type D personality and cardiac output in response to stress. Psychology \& Health, 24, 489-500. doi:10.1080/08870440701885616 
Damen, N.L., Versteeg, H., Helmondt, S.J. van, Jaegere, P.P. de, Geuns, R.J.M. van, Meine, M.M/m Domburg, R.T. van, Pedersen, S.S. The distressed (Type D) personality mediates the relationship between remembered parenting and psychological distress in cardiac patients.

Psychology \& Health: 2014, 29(3), 318-333

63. Williams, L., O'Connor, R. C., Grubb, N., \& O'Carroll, R. (2011). Type D personality predicts poor medication adherence in myocardial infarction patients. Psychology \& Health,

26, 703-712. doi:10.1080/08870446.2010.488265

64. Zigmond, A. S., \& Snaith, R. P. (1983). The hospital anxiety and depression scale. Acta Psychiatrica Scandinavica, 67, 361-370.

\section{TABLES AND FIGURES}

Figure 1. Mediation model for parental alienation and control, Type D personality and anxiety and depression.

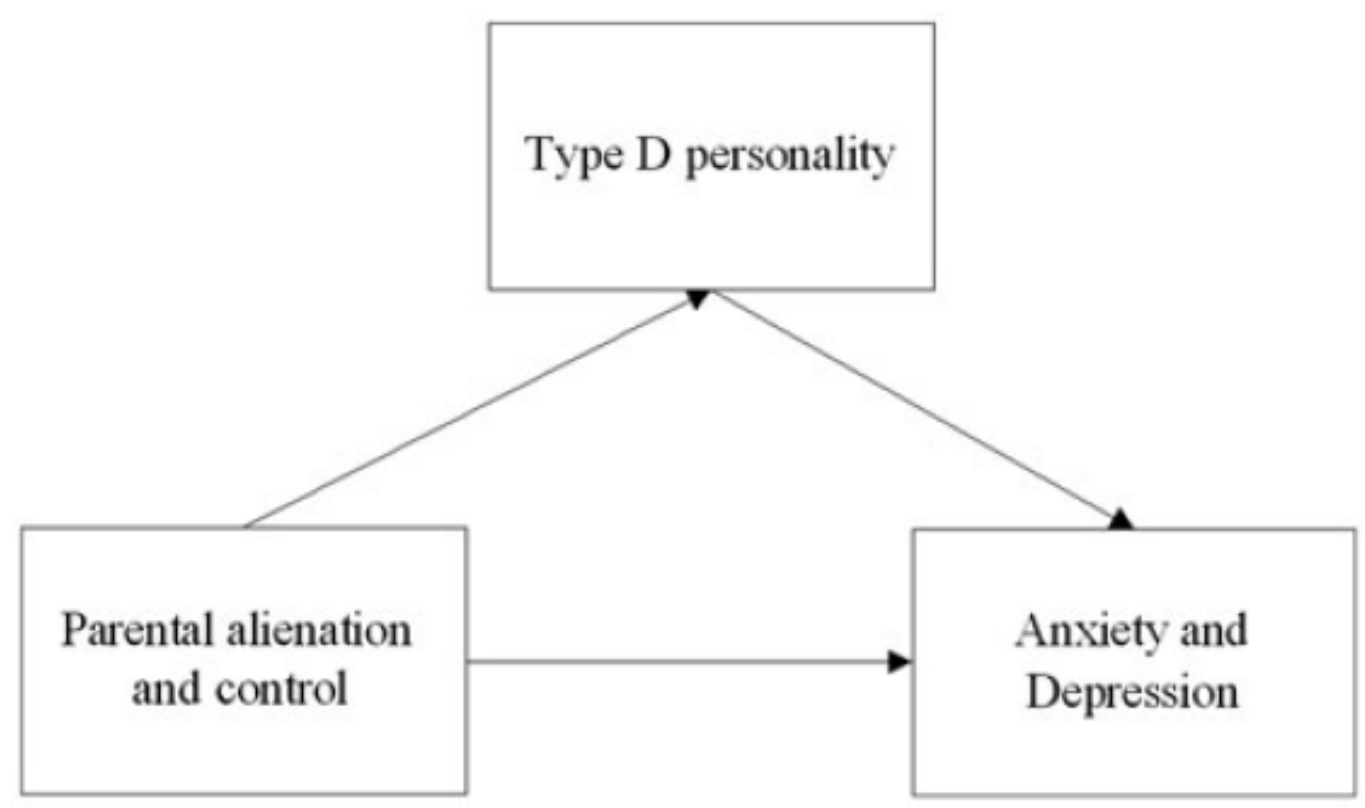


Damen, N.L., Versteeg, H., Helmondt, S.J. van, Jaegere, P.P. de, Geuns, R.J.M. van, Meine, M.M/m Domburg, R.T. van, Pedersen, S.S. The distressed (Type D) personality mediates the relationship between remembered parenting and psychological distress in cardiac patients 7

Psychology \& Health: 2014, 29(3), 318-333

Table 1. Patient characteristics for the total sample. ${ }^{a}$

\begin{tabular}{|c|c|c|}
\hline & PCI patients $(N=435)$ & CHF patients $(N=123)$ \\
\hline \multicolumn{3}{|l|}{ Socio-demographic characteristics } \\
\hline Male gender & $336(77.4)$ & $88(71.5)$ \\
\hline Age, mean (SD) & $62.6(10.7)$ & $65.3(10.5)$ \\
\hline \multicolumn{3}{|l|}{ Clinical characteristics } \\
\hline Cardiac history $^{\mathrm{b}}$ & $164(38.5)$ & $59(48.4)$ \\
\hline Hypertension & $208(53.1)$ & $47(38.2)$ \\
\hline Diabetes mellitus & $76(17.5)$ & $24(19.5)$ \\
\hline Self-reported smoking & $114(29.1)$ & $17(13.8)$ \\
\hline BMI, mean (SD) & $27.3(3.9)$ & $27.3(5.5)$ \\
\hline Multi-vessel disease & $221(51.0)$ & - \\
\hline Family history of CAD & $208(53.1)$ & - \\
\hline Indication for PCI & & - \\
\hline Stable angina & $174(40.7)$ & - \\
\hline Unstable angina & $110(25.8)$ & - \\
\hline$M I$ & $143(33.5)$ & - \\
\hline Ischaemic etiology & - & $64(52.0)$ \\
\hline CRT-D for primary prevention & - & $98(79.7)$ \\
\hline NYHA functional class III or IV & - & $99(80.5)$ \\
\hline LVEF, mean (SD) & - & $24.6(8.5)$ \\
\hline \multicolumn{3}{|l|}{ Cardiac medication } \\
\hline Aspirin & $423(97.7)$ & $38(30.9)$ \\
\hline ACE-inhibitors & $70(16.2)$ & $82(66.7)$ \\
\hline Beta-blockers & $302(69.7)$ & $94(76.4)$ \\
\hline Calcium-antagonists & $5(1.2)$ & $9(7.3)$ \\
\hline Diuretics & $4(.9)$ & $105(85.4)$ \\
\hline Oralnitrates & $61(14.1)$ & $21(17.1)$ \\
\hline Statins & $362(83.6)$ & $74(60.2)$ \\
\hline
\end{tabular}

Notes: ${ }^{\text {a}}$ Results are presented as $n(\%)$ unless otherwise stated.

${ }^{\mathrm{b}}$ Previous myocardial infarction (MI), percutaneous coronary intervention (PCI) or coronary artery bypass graft surgery $(\mathrm{CABG})$.

BMI $=$ Body mass index $\left(\mathrm{kg} / \mathrm{m}^{2}\right)$, CAD $=$ Coronary artery disease, CRT-D = cardiac resynchronization therapy defibrillator, LVEF $=$ Left ventricular ejection fraction, NYHA = New York Heart Association. 
Damen, N.L., Versteeg, H., Helmondt, S.J. van, Jaegere, P.P. de, Geuns, R.J.M. van, Meine, M.M/m Domburg, R.T. van, Pedersen, S.S. The distressed (Type D) personality mediates the relationship between remembered parenting and psychological distress in cardiac patients. Psychology \& Health: 2014, 29(3), 318-333
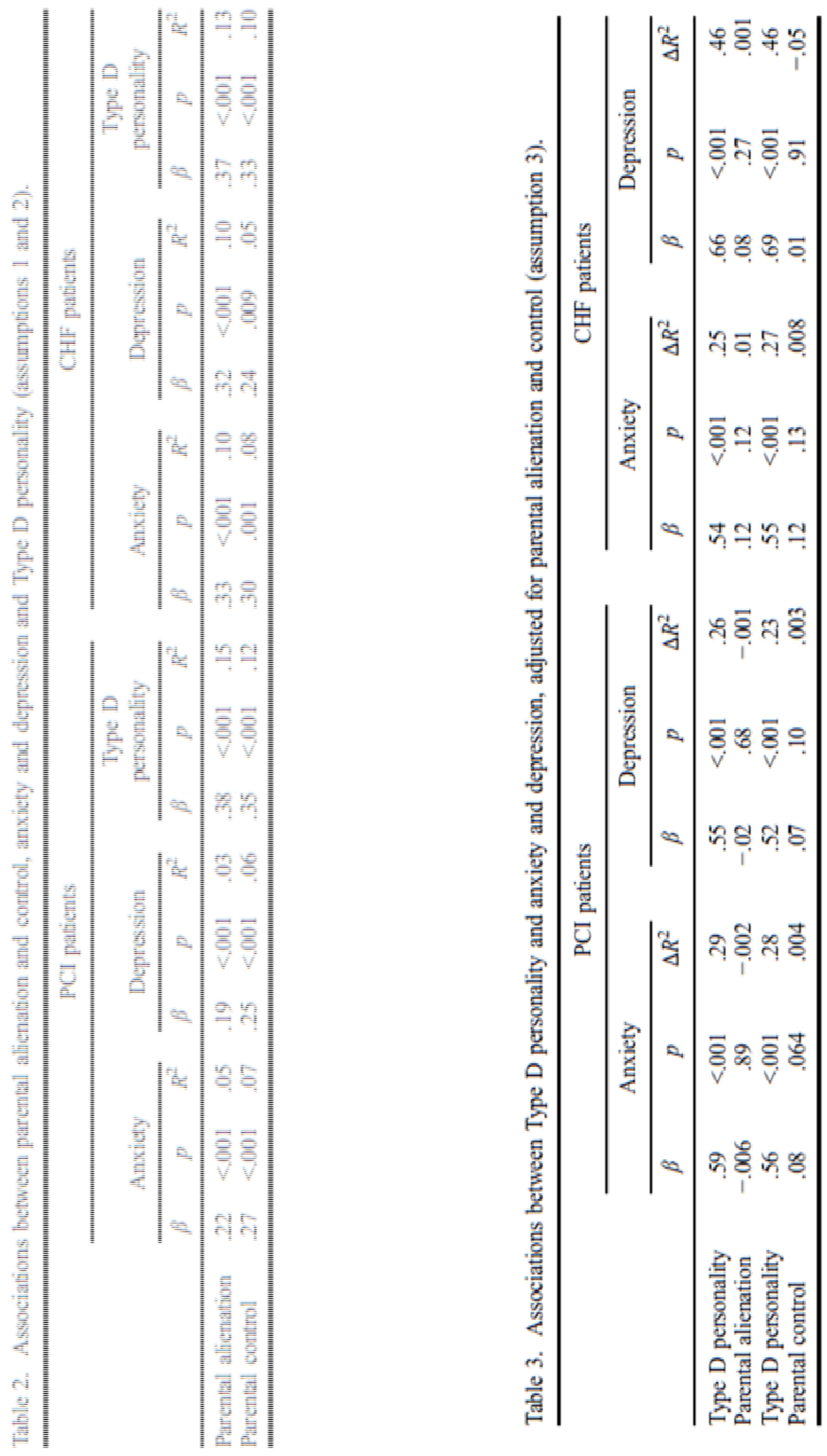